\title{
PRIMJENA STATISTIČKIH METODA I POSLOVNI REZULTATI PODUZEĆA U HRVATSKOJ: NEISKORIŠTENI POTENCIJAL
}

\author{
STATISTICAL METHODS USE AND BUSINESS RESULTS \\ OF ENTERPRISES IN CROATIA: UNUSED POTENTIAL
}

\begin{abstract}
SAŽETAK: Statističke metode namijenjene su pomaganju poduzećima u praćenju i poboljšanju postojećih poslovnih procesa te u donošenju poslovnih odluka. U radu se ispituje razina primjene statističkih metoda u poduzećima u Hrvatskoj te njihova veza s poslovnim rezultatima poduzeća. Provedeno web anketno istraživanje, u kojemu je primijenjen složen dizajn uzorkovanja, pokazalo je da samo kod srednje velikih i velikih poduzeća više od polovine poduzeća primjenjuje statističke metode u svojem poslovanju. Utvrđeno je da postoji statistički značajna razlika u prosječnoj vrijednosti ostvarene neto dobiti u 2016. godini između poduzeća koja primjenjuju statističke metode i poduzeća koja ih ne primjenjuju. Ovisno o promatranoj stratifikaciji, pokazalo se da poduzeća koja primjenjuju statističke metode imaju od 27,6 \% do 31,9\% veću šansu ostvarivanja pozitivne neto dobiti u odnosu na poduzeća koja ih ne primjenjuju. Međutim, ovaj zaključak vrijedi samo kad se promatraju poduzeća u cjelini. Dodatne analize pokazale su da duljina i učestalost primjene statističkih metoda nemaju statistički značajan utjecaj na vrijednost neto dobiti poduzeća. Zbog toga bi trebalo pridodati više pozornosti samoj kvaliteti primjene statističkih metoda i obrazovanju zaposlenih.
\end{abstract}

KLJUČNE RIJEČI: poduzeća u Hrvatskoj, poslovna web anketa, primjena statističkih metoda, složen dizajn ankete, stratifikacija.

JEL klasifikacija: C12, C25, C83, M20.

ABSTRACT: Statistical methods are helping enterprises to monitor and improve existing business processes, and make business decisions. In the paper statistical methods use and their connection to business results in enterprises in Croatia is observed. The conducted business web survey, in which complex survey design was applied, showed that only in midsized and large enterprises more than half of the enterprises use statistical methods in their

Doc. dr. sc. Berislav Žmuk, Sveučilište u Zagrebu, Ekonomski fakultet, Trg J. F. Kennedyja 6, HR-10000 Zagreb, Hrvatska, bzmuk@efzg.hr 
business. It has been shown that there is a statistically significant difference in the average value of net incomes achieved in 2016 between enterprises that use and that do not use statistical methods. Depending on the observed stratification, it has been shown that enterprises that use statistical methods have $27.6 \%$ to $31.9 \%$ greater odds to achieve positive net income in comparison to enterprises that do not use them. However, this conclusion is valid only if all enterprises are observed together. Additional analyses have shown that the length and frequency of the statistical methods use do not have a statistically significant effect on the net income. For this reason, more attention should be paid to the quality of the statistical methods use and to the education of employees.

KEY WORDS: business web survey, complex survey design, enterprises in Croatia, statistical methods use, stratification.

JEL Classification: C12, C25, C83, M20.

\section{UVOD}

Jedna od glavnih značajki suvremenog tržišnog poslovanja jest postojanje (određene) konkurencije. S aspekta potrošača postojanje konkurencije predstavlja poboljšanje njegove pregovaračke moći koje može rezultirati nižim cijenama i/ili boljim odnosno kvalitetnijim proizvodima i uslugama. S druge strane, postojanje konkurencije tjera poduzeća da neprestano rade na poboljšanju postojećih proizvoda i usluga, da uvode nove inovativne proizvode i usluge te da, općenito, rade na unapređenju svih procesa u poduzeću. Kako bi mogla provoditi konstantna unapređenja vlastitih proizvoda, usluga i poslovanja, poduzeća imaju na raspolaganju niz različitih metoda, tehnika, alata, politika, standarda te ostalih načina unapređenja. Jedan od mogućih načina unapređenja poslovanja poduzeća može se pronaći i u primjeni metoda statistike.

Primjena statističkih metoda javlja se daleko u prošlosti (Žmuk, 2013.). Ipak, za razliku od ranije, tek od 1662. godine počinju se zaista provoditi potpune statističke analize koje uključuju procese provođenja diskusije i zaključivanja (Rothman, 1996.). Sve dok razina tehnološkog razvoja nije to počela zahtijevati, statističke metode se nisu primjenjivale u poduzećima. Uslijed pojave masovne proizvodnje i pojave konkurencije, poduzeća su počela tražiti određene alate kojima bi mogli lakše pratiti, ali i unaprijediti, proizvodni proces. Navedeno su pronašli u pojavi tzv. primijenjene statistike početkom 20. stoljeća, područja statistike koje se fokusira upravo na razvoj statističkih metoda za potrebe poduzeća (Šolak, 1990.; Mast, Does, 2006.). Dakako, primjena statističkih metoda u to vrijeme bila je značajno složena te vremenski i znanjem zahtjevna (Ben-Zvi, Garfield, 2004.). Tek pojavom pristupačnih osobnih računala i statističkih programa početkom 80-ih godina 20. stoljeća, primjena statističkih metoda se počela intenzivirati u poduzećima (Van Matre, Gilbreath, 1987.).

Postoji nekoliko istraživanja u svezi primjene statističkih metoda u poduzećima u Hrvatskoj. Međutim, sva provedena istraživanja upućuju na to da se statističke metode slabo koriste u poduzećima iz Hrvatske, a ako se i koriste redovito je riječ o najjednostavnijim statističkim metodama (vidjeti Pejić Bach, Dumičić, Gogala, 1999.; Dumičić, 2004.; Gogala, Šimičević, 2005.; Ćurlin, 2006.; Dumičić, Knežević, 2007.; Šimičević, 2007.; Dumičić, Gajdić, 2011.; Žmuk, 2015.b). Dumičić, Bregar i Žmuk (2014.) su promatrajući mala po- 
duzeća u Hrvatskoj ustanovili da poduzeća koja primjenjuju statističke metode u prosjeku imaju veću vrijednost neto dobiti u odnosu na poduzeća koja ne primjenjuju statističke metode. U navedenome radu procijenjeno je da mala poduzeća koja primjenjuju statističke metode imaju 53,3\% veću šansu ostvarivanja pozitivne neto dobiti u odnosu na poduzeća koja ih ne primjenjuju. Promatrajući poduzeća iz Hrvatske u cjelini, bez obzira na njihovu veličinu, Žmuk (2015.a) je utvrdio da poduzeća koja primjenjuju statističke metode imaju $63,5 \%$ veće šanse ostvarivanja pozitivne neto dobiti od poduzeća koja ne primjenjuju statističke metode.

Rezultati istraživanja Dumičić, Bregar i Žmuk (2014.) i Žmuk (2015.a) temelje se na web anketnom istraživanju provedenome krajem 2012. godine. U međuvremenu, dogodila su se dva vrlo važna događaja koja su značajno utjecala na poduzeća u Hrvatskoj. Prvi važan događaj jest pristupanje Republike Hrvatske kao punopravne članice u Europsku uniju 1. srpnja 2013. godine (European Union, 2018.). Drugi važan događaj jest značajno smanjenje utjecaja globalne financijske krize čiji efekti su se počeli primjećivati u Hrvatskoj od 2009. godine (Bokan et al., 2009.). Stoga se postavlja istraživačko pitanje, kakvo je trenutačno stanje u svezi primjene statističkih metoda u poduzećima u Hrvatskoj te je li se razina utjecaja primjene statističkih metoda na rezultate poslovanja poduzeća značajnije promijenila. Sukladno postavljenim istraživačkim pitanjima definirane su dvije istraživačke hipoteze. U prvoj istraživačkoj hipotezi se pretpostavlja da više od polovine poduzeća u Hrvatskoj primjenjuje statističke metode u svojem poslovanju, dok se u drugoj istraživačkoj hipotezi smatra da poduzeća iz Hrvatske koja primjenjuju statističke metode imaju statistički značajno veće šanse ostvarivanja pozitivne neto dobiti u odnosu na poduzeća koja ih ne primjenjuju. Potrebno je istaknuti da se u radu uspješnost poslovanja poduzeća promatra samo s perspektive primjene statističkih metoda. Međutim, uspješnost poslovanja poduzeća ovisi o nizu različitih čimbenika koji se nalaze u samom poduzeću, ali i u njegovom okruženju (Žager et al., 2008.).

Rad je organiziran kako slijedi. Nakon uvodnoga dijela, u drugome dijelu rada se opisuje korištena metodologija prikupljanja podataka te se objašnjava pristup i metode koje će se koristiti u analizi prikupljenih podataka. U trećemu dijelu rada iznose se rezultati provedenih statističkih analiza te se provodi njihova diskusija. U posljednjemu dijelu rada daju se zaključna razmatranja, navode se glavna ograničenja rada te se iznose preporuke za buduća istraživanja.

\section{METODOLOGIJA ISTRAŽIVANJA}

Za potrebe rada provedeno je anketno istraživanje na uzorku poduzeća iz Hrvatske u razdoblju od listopada do prosinca 2016. godine. Pod pojmom „poduzeća iz Hrvatske“ podrazumijevaju se trgovačka društva koja pripadaju grupi društva kapitala. Sukladno Zakonu o trgovačkim društvima (Narodne novine, 2011., 2012.) u društvo kapitala spadaju poduzeća koja su prema pravnome obliku dioničko društvo, društvo s ograničenom odgovornošću ili jednostavno društvo s ograničenom odgovornošću. Navedena vrsta poduzeća je izabrana zbog njihove obveze, sukladno Zakonu o računovodstvu (Narodne novine, 2015.), sa sastavljanjem i objavom godišnjih financijskih izvještaja. Poduzeće se smatra hrvatskim ako je ono registrirano kod odgovarajućeg trgovačkog suda u Republici Hrvatskoj. 
Anketno istraživanje provedeno je na temu primjene statističkih metoda u redovitom poslovanju poduzeća. Anketni upitnik napravljen je u dvije inačice. U ovisnosti o odgovoru na prvo, filtarsko, pitanje poduzeća koja primjenjuju statističke metode u svojem poslovanju dobila su na ispunjavanje jednu inačicu anketnog upitnika dok poduzeća koja ne primjenjuju statističke metode u svojem poslovanju su dobila drugu inačicu upitnika. Predviđeno potrebno vrijeme ispunjavanja prve inačice anketnog upitnika, koju ispunjavaju poduzeća koja primjenjuju statističke metode, je 15 minuta, a druge inačice anketnog upitnika, koju ispunjavaju poduzeća koja ne primjenjuju statističke metode, je 5 minuta. Sukladno navedenome, ovi anketni upitnici se mogu smatrati srednje dugim odnosno kratkim (1KA, 2018.), a što bi trebalo pozitivno utjecati na stopu odgovora koja je u ovakvima istraživanjima niska i u konstantnom opadanju (Schwarz, 2013.). Ipak, usprkos relativnoj kratkoći anketnih upitnika i slanju dvaju podsjetnika, od 37.859 poduzeća, koja su bila pozvana na sudjelovanje u istraživanju, njih 780 je anketni upitnik ispunilo u cijelosti dok je 496 poduzeća anketni upitnik popunilo samo djelomično. Shodno tome, ako se promatra broj popunjenih anketnih upitnika u cijelosti i broj djelomično popunjenih anketnih upitnika zajedno, može se zaključiti da je ostvarena stopa odgovora od 3,37 \%. Stope odgovora promatrane po različitim stratumima poduzeća su dane u tablici 1.

Tablica 1: Analiza značajki uzorka prema odabranim stratumima poduzeća

\begin{tabular}{|l|r|r|r|c|}
\hline \multicolumn{1}{|c|}{ Stratum poduzeća } & $\begin{array}{c}\text { Istraživana } \\
\text { populacija }\end{array}$ & $\begin{array}{c}\text { Veličina } \\
\text { uzorka }\end{array}$ & $\begin{array}{c}\text { Stopa } \\
\text { odgovora (\%) }\end{array}$ & $\begin{array}{c}\text { Ponder prilagodbe } \\
\text { zbog neodgovora }\end{array}$ \\
\hline Veličina poduzeća & 36.390 & 1.216 & 3,34 & 29,9260 \\
\hline Malo & 1.134 & 47 & 4,14 & 24,1277 \\
\hline Srednje & 335 & 13 & 3,88 & 25,7692 \\
\hline Veliko & 11.270 & 361 & 3,20 & 31,2188 \\
\hline Glavna djelatnost poduzeća & 9.594 & 275 & 2,87 & 34,8873 \\
\hline Industrija & 15.793 & 596 & 3,77 & 26,4983 \\
\hline Trgovina & 1.202 & 44 & 3,66 & 27,3182 \\
\hline Usluge & 17.080 & 652 & 3,82 & 26,1963 \\
\hline Ostalo & 6.373 & 177 & 2,78 & 36,0056 \\
\hline Lokacija sjedišta poduzeća & 14.406 & 447 & 3,10 & 32,2282 \\
\hline $\begin{array}{l}\text { Sjeverozapadna } \\
\text { Hrvatska }\end{array}$ & $\begin{array}{l}\text { Središnja i Istočna } \\
\text { Hrvatska }\end{array}$ & & & \\
\hline Jadranska Hrvatska & \multicolumn{5}{|l|}{} \\
\hline
\end{tabular}

Izvor: izrada autora.

Osim u cjelini, anketirana poduzeća će se promatrati i prema njihovim glavnim značajkama. Sukladno tome, poduzeća će se stratificirati sukladno sljedećim značajkama: veličini poduzeća, glavnoj djelatnosti poduzeća te prema lokaciji mjesta sjedišta poduzeća. Stratifikacija poduzeća prema veličini će se napraviti u skladu sa Zakonom o računovodstvu (Narodne novine, 2015.), a prema kojemu se razlikuju mala, srednje velika te velika podu- 
zeća. Stratifikacija poduzeća prema glavnoj djelatnosti napravljena je u skladu s Nacionalnom klasifikacijom djelatnosti (Narodne novine, 2007.). Međutim, zbog postojanja čak 21 područja djelatnosti odlučeno je da će se ta područja grupirati. Na taj način formirana su četiri stratuma djelatnosti poduzeća u kojima se nalaze industrijska, trgovinska, uslužna te ostala poduzeća. Naposljetku, poduzeća će se stratificirati prema lokaciji sjedišta poduzeća te će se pritom primijeniti nomenklatura statističkih prostornih jedinica s višestrukim razinama kodovima (Eurostat, 2011.). Budući da se na prvoj razini Republika Hrvatska promatra kao jedna jedinica u cjelini, u radu će promatrati podjela prema drugoj razini, a prema kojoj se definiraju sljedeće tri regije: Sjeverozapadna Hrvatska, Središnja i Istočna (Panonska) Hrvatska, te Jadranska Hrvatska. Distribucija poduzeća po stratumima detaljno je prikazana u tablici 1 .

Ranije je naznačeno da je ostvarena relativno niska stopa odgovora. Kako bi se provela nadoknada za poduzeća koja nisu odgovorila na anketni upitnik, odlučeno je kako će se primijeniti ponder prilagodbe zbog neodgovora (Heeringa, West, Berglund, 2010.). Prilikom utvrđivanja vrijednosti pondera primijenit će se metoda klase ponderiranja (Little, Rubin, 2002.). Prema toj metodi ponder poprima recipročnu vrijednost stope odgovora kod promatranoga stratuma. Budući da se neće primjenjivati dodatni ponderi, dobiveni ponderi će biti ujedno i konačni. Vrijednosti pondera prilagodbe zbog neodgovora prikazani po stratumima poduzeća prikazani su u tablici 1. Radi održavanja jednostavnosti interpretacije i donošenja zaključaka, poduzeća se neće promatrati po svim stratumima istovremeno nego odvojeno po određenom stratumu.

U analizi će se koristiti ukupno pet glavnih varijabli. Prva varijabla sadrži informaciju o tome koristi li poduzeće, bilo samostalno ili uz pomoć vanjskih suradnika, statističke metode ili ne. Sljedeća varijabla sadrži informaciju o tome koliko dugo se, mjereno u godinama, koriste statističke metode u poduzećima koja ih primjenjuju. Osim duljine prakse primjene statističkih metoda u poduzećima, promatrat će se i njihova učestalost primjene. Učestalost primjene statističkih metoda općenito će se definirati prema učestalosti primjene metoda deskriptivne statistike koje uključuju početne i osnovne metode statističke analize na kojima se temelje ostale metode statističke analize. Ukupno su definirane tri razine učestalosti primjene statističkih metoda: često (ako se metode deskriptivne statistike primjenjuju u prosjeku barem jednom tjedno); rijetko (ako se metode deskriptivne statistike u prosjeku primjenjuju na mjesečnoj ili godišnjoj razini) te vrlo rijetko (ako se metode deskriptivne statistike u prosjeku primjenjuju rjeđe od jednom godišnje). Podaci za dosada navedene varijable preuzet će se iz provedenoga anketnog istraživanja dok će se podaci za preostale četiri varijable preuzeti iz godišnjih financijskih izvještaja poduzeća. Budući da se želi ispitati veza između primjene statističkih metoda i ostvarenih poslovnih rezultata poduzeća, u analizi će se promatrati još i poslovni prihodi te neto dobit poduzeća. Vrijednosti obje varijable promatrat će se za 2016. godinu. U tablici 2. dan je popis varijabli te njihov kratak opis.

Prema podacima iz tablice 2. primjećuje se kako se ne raspolaže sa svim podacima za poduzeća iz uzorka. Uzrok tome moguće je pronaći u činjenici da nisu sva poduzeća u potpunosti ispunila anketni upitnik. Također, određena poduzeća su proglašena neaktivnima, nisu dostavila godišnje financijske izvještaje ili su, u međuvremenu, likvidirana. Iz toga razloga će biti potrebno ponovno izračunavati pondere prilagodbe zbog neodgovora kada se $\mathrm{u}$ analizi budu koristile one varijable za koje se ne raspolaže s podacima za sva poduzeća iz uzorka. 
Tablica 2: Varijable korištene u analizi

\begin{tabular}{|l|l|c|c|}
\hline $\begin{array}{c}\text { Kod } \\
\text { varijable }\end{array}$ & \multicolumn{1}{|c|}{ Opis varijable } & $\begin{array}{c}\text { Broj } \\
\text { podataka }\end{array}$ & $\begin{array}{c}\text { Postotak nedostajućih } \\
\text { vrijednosti (\%) }\end{array}$ \\
\hline PrimStat & $\begin{array}{l}\text { Primjena statističkih metoda u } \\
\text { poduzeću (modaliteti: da, ne) }\end{array}$ & 1.276 & 0,00 \\
\hline DuljStat & $\begin{array}{l}\text { Duljina primjene statističkih metoda } \\
\text { u poduzeću, u godinama (numerička } \\
\text { varijabla) }\end{array}$ & 454 & 30,69 \\
\hline UcesStat & $\begin{array}{l}\text { Učestalost primjene statističkih metoda } \\
\text { (modaliteti: često, rijetko, vrlo rijetko) }\end{array}$ & 340 & 48,09 \\
\hline PPrih16 & $\begin{array}{l}\text { Poslovni prihodi poduzeća u 2016. } \\
\text { godini, u kunama (numerička varijabla) }\end{array}$ & 1.239 & 2,90 \\
\hline Dobit16 & $\begin{array}{l}\text { Neto dobit poduzeća u 2016. godini, u } \\
\text { kunama (numerička varijabla) }\end{array}$ & 1.241 & 2,74 \\
\hline
\end{tabular}

Izvor: izrada autora.

Prilikom provođenja analize uzet će se u obzir primijenjeni složeni dizajn anketnog istraživanja, a koji uključuje stratifikaciju i uključivanje pondera. Također će se, kada će to biti moguće, prikazati podatak o vrijednosti efekta dizajna. Prilikom procjene varijance primijenit će se Jackknife ponovljena metoda replikacije (eng. Jackknife Repeated Replication - JRR) (Rust, Rao, 1996, Heeringa, West, Berglund, 2010.). U analizi će se primijeniti odabrane metode inferencijalne statistike za procjenu proporcije te aritmetičke sredine. Metode regresijske i korelacijske analize će također biti korištene u ispitivanju veze između primjene statističkih metoda i ostvarenih poslovnih rezultata poduzeća.

\section{ANALIZA VEZE IZMEĐU PRIMJENE STATISTIČKIH METODA I POSLOVNIH REZULTATA PODUZEĆA}

\subsection{Primjena statističkih metoda u poduzećima u Hrvatskoj}

Odluka o primjeni statističkih metoda može ovisiti o puno različitih značajki poduzeća, ali i vlasnika, menadžera i ostalih zaposlenih. U ovome radu izdvojene su ukupno tri značajke poduzeća prema kojima će se razmatrati primjena statističkih metoda. Prva takva značajka jest veličina poduzeća, a prema kojoj su definirane tri grupe odnosno tri stratuma poduzeća. Rezultati o primjeni statističkih metoda u poduzećima u Hrvatskoj promatrano prema njihovoj veličini te koji uzimaju u obzir složen dizajn uzorka su prikazani u tablici 3.

Rezultati iz tablice 3. otkrivaju kako je u anketnom istraživanju sudjelovalo najviše malih poduzeća (1.216 poduzeća), zatim srednjih (47 poduzeća), a najmanje je sudjelovalo velikih poduzeća, njih samo 13 . Za svaku od tih skupina poduzeća posebno je iskazana proporcija poduzeća koja statističke metode primjenjuju odnosno koja ih ne primjenjuju. Potrebno je istaknuti da se prilikom izračuna proporcija polazi od vrijednosti pondera, a ne od veličine uzorka. 
Prema procijenjenim proporcijama, ispada da se statističke metode primjenjuju u najvećem udjelu kod velikih poduzeća $(0,9231)$, zatim kod srednje velikih poduzeća $(0,6809)$, a najmanje kod malih poduzeća $(0,5025)$. Empirijska vrijednost provedenoga Rao-Scott F testa drugog reda, kod kojega nulta hipoteza glasi da veličina poduzeća nije povezana s primjenom statističkih metoda iznosi 12,3883 (stupnjevi slobode za brojnik $=1,66$, stupnjevi slobode za nazivnik $=2.109,11$, p vrijednost $<0,0001$ ). Prema tome, uz razinu signifikantnosti od $5 \%$ odbacuje se nulta hipoteza da veličina poduzeća i primjena statističkih metoda nije povezana. Dakle, udio poduzeća koja primjenjuju statističke metode se razlikuje ovisno o veličini poduzeća (SAS, 2018.).

Tablica 3: Primjena statističkih metoda u poduzećima iz Hrvatske, stratifikacija prema veličini poduzeća, $n=1276$

\begin{tabular}{|l|l|r|r|r|r|r|r|r|}
\hline \multirow{2}{*}{$\begin{array}{c}\text { Veličina } \\
\text { poduzeća }\end{array}$} & $\begin{array}{c}\text { Primje- } \\
\text { na sta- } \\
\text { tističkih } \\
\text { metoda }\end{array}$ & $\begin{array}{c}\text { Veli- } \\
\text { čina } \\
\text { uzor- } \\
\text { ka }\end{array}$ & $\begin{array}{c}\text { Zbroj } \\
\text { ponde- } \\
\text { ra }\end{array}$ & $\begin{array}{c}\text { Propor- } \\
\text { cija }\end{array}$ & $\begin{array}{c}\text { Standardna } \\
\text { pogreška } \\
\text { proporcija }\end{array}$ & $\begin{array}{c}\text { 95 \% interval } \\
\text { pouzdanosti } \\
\text { procjene } \\
\text { proporcije }\end{array}$ & $\begin{array}{c}\text { Efekt } \\
\text { dizajna }\end{array}$ \\
\hline \multirow{2}{*}{ Malo } & $\mathrm{Da}$ & 611 & 18.285 & 0,5025 & 0,0143 & 0,4743 & 0,5306 & 0,9706 \\
\cline { 2 - 10 } & $\mathrm{Ne}$ & 605 & 18.105 & 0,4975 & 0,0143 & 0,4694 & 0,5257 & 0,9713 \\
\hline \multirow{2}{*}{ Srednje } & $\mathrm{Da}$ & 32 & 772,09 & 0,6809 & 0,0687 & 0,5460 & 0,8157 & 0,2705 \\
\cline { 2 - 9 } & $\mathrm{Ne}$ & 15 & 361,91 & 0,3191 & 0,0687 & 0,1843 & 0,4540 & 0,5707 \\
\hline \multirow{2}{*}{ Veliko } & $\mathrm{Da}$ & 12 & 309,23 & 0,9231 & 0,0769 & 0,7722 & 1,0000 & 0,0729 \\
\cline { 2 - 10 } & $\mathrm{Ne}$ & 1 & 25,77 & 0,0769 & 0,0769 & 0,0000 & 0,2278 & 0,8984 \\
\hline \multirow{2}{*}{ Ukupno } & $\mathrm{Da}$ & 655 & 19.366 & 0,5115 & 0,0140 & 0,4842 & 0,5389 & 0,9940 \\
\cline { 2 - 9 } & $\mathrm{Ne}$ & 621 & 18.493 & 0,4885 & 0,0140 & 0,4611 & 0,5158 & 0,9940 \\
\hline
\end{tabular}

Izvor: izrada autora.

Posljednji stupac tablice 3. otkriva da su sve vrijednost efekta dizajna manje od 1. Sukladno tome može se zaključiti da je zbog stratifikacije došlo do povećanja preciznosti procjena. Drugim riječima, varijance dobivene stratifikacijom su manje od varijanci koje bi se dobile ako bi se primijenio jednostavni slučajni dizajn uzorka. U nastavku se, također, može zaključiti da je efektivna veličina uzorka odnosno veličina uzorka kod jednostavnog slučajnog uzorkovanja potrebna kako bi se ostvarila ista razina preciznosti, veća od onih prikazanih u tablici 3. (Kish, 1995.). 
Tablica 4: Primjena statističkih metoda u poduzećima iz Hrvatske, stratifikacija prema glavnoj djelatnosti poduzeća, $n=1276$

\begin{tabular}{|l|l|r|r|r|c|c|c|c|}
\hline $\begin{array}{c}\text { Glavna } \\
\text { djelatnost } \\
\text { poduzeća }\end{array}$ & $\begin{array}{c}\text { Primje- } \\
\text { na sta- } \\
\text { tističkih } \\
\text { metoda }\end{array}$ & $\begin{array}{c}\text { Veli- } \\
\text { cina } \\
\text { uzor- } \\
\text { ka }\end{array}$ & $\begin{array}{c}\text { Zbroj } \\
\text { pon- } \\
\text { dera }\end{array}$ & $\begin{array}{c}\text { Pro- } \\
\text { porcija }\end{array}$ & $\begin{array}{c}\text { Stan- } \\
\text { dardna } \\
\text { pogreška } \\
\text { proporcija }\end{array}$ & $\begin{array}{c}\text { 95 \% interval } \\
\text { pouzdanosti } \\
\text { procjene } \\
\text { proporcije }\end{array}$ & $\begin{array}{c}\text { Efekt } \\
\text { dizajna }\end{array}$ \\
\hline \multirow{2}{*}{ Industrijska } & $\mathrm{Da}$ & 190 & 5.932 & 0,5263 & 0,0263 & 0,4747 & 0,5779 & 0,5922 \\
\cline { 2 - 10 } & $\mathrm{Ne}$ & 171 & 5.338 & 0,4737 & 0,0263 & 0,4221 & 0,5253 & 0,6460 \\
\hline \multirow{2}{*}{ Trgovinska } & $\mathrm{Da}$ & 147 & 5.128 & 0,5345 & 0,0301 & 0,4754 & 0,5937 & 0,6349 \\
\cline { 2 - 10 } & $\mathrm{Ne}$ & 128 & 4.466 & 0,4655 & 0,0301 & 0,4063 & 0,5246 & 0,7146 \\
\hline \multirow{2}{*}{ Uslužna } & $\mathrm{Da}$ & 292 & 7.738 & 0,4899 & 0,0205 & 0,4497 & 0,5301 & 0,5731 \\
\cline { 2 - 10 } & $\mathrm{Ne}$ & 304 & 8.055 & 0,5101 & 0,0205 & 0,4699 & 0,5503 & 0,5563 \\
\hline \multirow{2}{*}{ Ostalo } & $\mathrm{Da}$ & 26 & 710,27 & 0,5909 & 0,0750 & 0,4438 & 0,7380 & 0,3925 \\
\cline { 2 - 10 } & $\mathrm{Ne}$ & 18 & 491,73 & 0,4091 & 0,0750 & 0,2620 & 0,5562 & 0,5636 \\
\hline \multirow{2}{*}{ Ukupno } & $\mathrm{Da}$ & 655 & 19.508 & 0,5153 & 0,0141 & 0,4876 & 0,5429 & 1,0130 \\
\cline { 2 - 9 } & $\mathrm{Ne}$ & 621 & 18.351 & 0,4847 & 0,0141 & 0,4571 & 0,5124 & 1,0130 \\
\hline
\end{tabular}

Izvor: izrada autora.

U tablici 4. daju se rezultati primjene statističkih metoda promatrano prema glavnoj djelatnosti poduzeća. Za razliku kada su se poduzeća promatrala prema veličini, kada se poduzeća promatraju prema glavnoj djelatnosti razlika u udjelu odnosno proporciji poduzeća koja primjenjuju statističke metode između stratuma je daleko manje izraženija. Najvišu proporciju poduzeća koja primjenjuju statističke metode imaju poduzeća čija djelatnost spada u kategoriju ostalo $(0,5909)$, zatim slijede trgovinska poduzeća $(0,5345)$ i industrijska poduzeća $(0,5263)$, dok je udio poduzeća koja primjenjuju statističke metode kod uslužnih poduzeća najmanji $(0,4899)$. Shodno tome, rezultat provedenoga Rao-Scott F testa drugoga reda nije iznenađujući (empirijski $\mathrm{F}=0,9812$, stupnjevi slobode za brojnik $=2,98$, stupnjevi slobode za nazivnik $=3.784,32, \mathrm{p}$ vrijednost $=0,4001$ ). Dakle, uz razinu signifikantnosti od $5 \%$ nulta hipoteza testa se ne može odbaciti te se sukladno tome zaključuje kako se udio poduzeća koja primjenjuju statističke metode ne razlikuje statistički značajno ovisno o glavnoj djelatnosti poduzeća. 
Tablica 5: Primjena statističkih metoda u poduzećima iz Hrvatske, stratifikacija prema lokaciji poduzeća, $\mathrm{n}=1276$

\begin{tabular}{|c|c|c|c|c|c|c|c|c|}
\hline $\begin{array}{l}\text { Lokacija } \\
\text { poduzeća }\end{array}$ & $\begin{array}{c}\text { Primje- } \\
\text { na sta- } \\
\text { tističkih } \\
\text { metoda }\end{array}$ & $\begin{array}{c}\text { Veli- } \\
\text { čina } \\
\text { uzor- } \\
\text { ka }\end{array}$ & $\begin{array}{l}\text { Zbroj } \\
\text { pon- } \\
\text { dera }\end{array}$ & $\begin{array}{c}\text { Pro- } \\
\text { porcija }\end{array}$ & $\begin{array}{c}\text { Stan- } \\
\text { dardna } \\
\text { pogreška } \\
\text { proporcija }\end{array}$ & \multicolumn{2}{|c|}{$\begin{array}{c}95 \% \text { interval } \\
\text { pouzdanosti } \\
\text { procjene } \\
\text { proporcije }\end{array}$} & $\begin{array}{c}\text { Efekt } \\
\text { dizajna }\end{array}$ \\
\hline \multirow{2}{*}{$\begin{array}{l}\text { Sjeveroza- } \\
\text { padna Hrvat- } \\
\text { ska }\end{array}$} & $\mathrm{Da}$ & 340 & 8.907 & 0,4922 & 0,0237 & 0,4457 & 0,5386 & 0,5529 \\
\hline & $\mathrm{Ne}$ & 312 & 8.173 & 0,5078 & 0,0237 & 0,4614 & 0,5543 & 0,5876 \\
\hline \multirow{2}{*}{$\begin{array}{l}\text { Središnja } \\
\text { i Istočna } \\
\text { Hrvat. }\end{array}$} & $\mathrm{Da}$ & 95 & 3.421 & 0,5215 & 0,0196 & 0,4831 & 0,5599 & 0,6211 \\
\hline & $\mathrm{Ne}$ & 82 & 2.952 & 0,4785 & 0,0196 & 0,4401 & 0,5169 & 0,7099 \\
\hline \multirow{2}{*}{$\begin{array}{l}\text { Jadranska } \\
\text { Hrvatska }\end{array}$} & $\mathrm{Da}$ & 220 & 7.090 & 0,5367 & 0,0376 & 0,4630 & 0,6105 & 0,6797 \\
\hline & $\mathrm{Ne}$ & 227 & 7.316 & 0,4633 & 0,0376 & 0,3895 & 0,5370 & 0,6636 \\
\hline \multirow{2}{*}{ Ukupno } & $\mathrm{Da}$ & 655 & 19.417 & 0,5129 & 0,0141 & 0,4852 & 0,5406 & 1,0166 \\
\hline & $\mathrm{Ne}$ & 621 & 18.442 & 0,4871 & 0,0141 & 0,4594 & 0,5148 & 1,0166 \\
\hline
\end{tabular}

Izvor: izrada autora.

Prema podacima iz tablice 5, udio poduzeća koja primjenjuju statističke metode najveći je u poduzećima iz Jadranske Hrvatske (0,5367), zatim iz Središnje i Istočne Hrvatske $(0,5215)$, dok je najmanji udio prisutan kod poduzeća iz Sjeverozapadne Hrvatske $(0,4922)$. Empirijska vrijednost provedenoga Rao-Scott F testa drugoga reda iznosi 0,6884 (stupnjevi slobode za brojnik $=1,98$, stupnjevi slobode za nazivnik $=2.524,86$, $\mathrm{p}$ vrijednost $=0,5013$ ). Sukladno tome, uz razinu signifikantnosti od $5 \%$ nulta hipoteza testa se ne može odbaciti. Prema tome zaključuje se kako se udio poduzeća koja primjenjuju statističke metode ne razlikuje statistički značajno ovisno o lokaciji poduzeća. 
Tablica 6: Rezultati jednosmjernih testova hipoteze o pretpostavljenoj vrijednosti proporcije na gornju granicu o primjeni statističkih metoda u poduzećima iz Hrvatske, pretpostavljena vrijednost proporcije 0,5

\begin{tabular}{|c|c|c|c|c|c|c|}
\hline Stratifikacija & Stratum & $\begin{array}{l}\text { Veličina } \\
\text { uzorka }\end{array}$ & Proporcija & $\begin{array}{c}\text { Standardna } \\
\text { pogreška }\end{array}$ & $\begin{array}{c}\mathbf{Z} \\
\text { vrijed. }\end{array}$ & $\begin{array}{c}\mathbf{p} \\
\text { vrijed. }\end{array}$ \\
\hline \multirow{4}{*}{$\begin{array}{l}\text { Veličina } \\
\text { poduzeća }\end{array}$} & Malo & 1.216 & 0,5025 & 0,0143 & 0,17 & 0,4308 \\
\hline & Srednje & 47 & 0,6809 & 0,0729 & 2,48 & 0,0066 \\
\hline & Veliko & 13 & 0,9231 & 0,1387 & 3,05 & 0,0011 \\
\hline & Ukupno & 1.276 & 0,5115 & 0,0140 & 0,82 & 0,2057 \\
\hline \multirow{5}{*}{$\begin{array}{l}\text { Glavna } \\
\text { djelatnost } \\
\text { poduzeća }\end{array}$} & Industrijska & 361 & 0,5263 & 0,0263 & 1,00 & 0,1588 \\
\hline & Trgovinska & 275 & 0,5345 & 0,0302 & 1,14 & 0,1263 \\
\hline & Uslužna & 596 & 0,4899 & 0,0205 & $-0,49$ & 0,6890 \\
\hline & Ostalo & 44 & 0,5909 & 0,0754 & 1,21 & 0,1139 \\
\hline & Ukupno & 1.276 & 0,5153 & 0,0140 & 1,09 & 0,1372 \\
\hline \multirow{4}{*}{$\begin{array}{l}\text { Lokacija } \\
\text { poduzeća }\end{array}$} & $\begin{array}{l}\text { Sjeverozapadna } \\
\text { Hrvatska }\end{array}$ & 652 & 0,4922 & 0,0196 & $-0,40$ & 0,6548 \\
\hline & $\begin{array}{l}\text { Središnja i } \\
\text { Istočna Hrvat. }\end{array}$ & 177 & 0,5215 & 0,0376 & 0,57 & 0,2836 \\
\hline & $\begin{array}{l}\text { Jadranska } \\
\text { Hrvatska }\end{array}$ & 447 & 0,5367 & 0,0236 & 1,55 & 0,0603 \\
\hline & Ukupno & 1.276 & 0,5129 & 0,0140 & 0,92 & 0,1784 \\
\hline
\end{tabular}

Napomena: p vrijednost je dana za jednosmjeran test.

Izvor: izrada autora.

U svrhu ispitivanja prve istraživačke hipoteze rada, prema kojoj više od polovine poduzeća iz Hrvatske primjenjuje statističke metode u svojem poslovanju, provedeni su odgovarajući jednosmjerni testovi hipoteze o pretpostavljenoj vrijednosti proporcije na gornju granicu. Prilikom provođenja testova promatrana je proporcija poduzeća koja primjenjuje statističke metode. Testovi su provedeni za svaku provedenu stratifikaciju poduzeća zasebno. Prema rezultatima iz tablice 6 , na razini signifikantnosti od $5 \%$ pokazalo se da se samo kod srednje velikih i velikih poduzeća nulta hipoteza testa o pretpostavljenoj vrijednosti proporcije može odbaciti. Drugim riječima, zaključuje se da samo kod srednje velikih i velikih poduzeća više od polovine poduzeća primjenjuje statističke metode u svojem poslovanju. Ipak, kada se promatraju sva poduzeća u cjelini, navedeni zaključak se na uobičajeno korištenim razinama signifikantnosti ne može donijeti. Sukladno tome, prva istraživačka hipoteza rada se ne može prihvatiti.

\subsection{Veza između primjene statističkih metoda i poslovnih rezultata poduzeća}

Nakon ispitivanja primjenjuju li se statističke metode u poduzećima iz Hrvatske ili ne, u ovome poglavlju razmatrat će se veza i utjecaj primjene statističkih metoda na poslovne rezultate poduzeća. Zbog iznimne heterogenosti poduzeća, od poslovnih rezultata promatrat će se samo poslovni prihodi i neto dobit poduzeća ostvareni u 2016. godini, 
krajem koje je i bilo provedeno anketno istraživanje. Dodatni razlog zašto su odabrane navedene kategorije leži u činjenici da su poduzeća dužna u svojim godišnjim financijskim izvješćima dostaviti podatke o njihovoj vrijednosti. Nažalost, pokazalo se da ipak nisu sva poduzeća dostavila godišnje financijske izvještaje u propisanim zakonskim rokovima, a najvjerojatnije niti ih neće dostaviti zbog likvidacije, proglašenja stečaja, neaktivnosti i ostalih razloga. Posljedično, broj poduzeća koji će se promatrati u nastavku je nešto manji od broja poduzeća koja su sudjelovala u istraživanju. U tablici 7. prikazana je usporedba ostvarenih prosječnih poslovnih prihoda u 2016. godini između poduzeća koja primjenjuju statističke metode u svojem poslovanju te poduzeća koja ih ne primjenjuju.

Tablica 7: Primjena statističkih metoda i poslovni rezultati poduzeća iz Hrvatske, poslovni prihodi poduzeća u 2016. godini, u milijunima kuna, $\mathrm{n}=1239$

\begin{tabular}{|c|c|c|c|c|c|c|c|c|c|}
\hline Stratif. & Stratum & $\begin{array}{c}\text { Primjena } \\
\text { stat. } \\
\text { metoda }\end{array}$ & $\begin{array}{c}\text { Vel. } \\
\text { uzorka }\end{array}$ & $\begin{array}{l}\text { Arit. } \\
\text { sredina }\end{array}$ & $\begin{array}{l}\text { Stand. pog. } \\
\text { procjene } \\
\text { arit. sred. }\end{array}$ & $\begin{array}{r}95 \% \text { i } \\
\text { pouzd. } 1 \\
\text { arit. }\end{array}$ & $\begin{array}{l}\text { terval } \\
\text { rocjene } \\
\text { red. }\end{array}$ & $\begin{array}{c}\mathrm{t} \\
\text { vrijed. }\end{array}$ & $\underset{\text { vrijed. }}{p}$ \\
\hline \multirow{8}{*}{$\begin{array}{l}\text { Veličina } \\
\text { poduzeća }\end{array}$} & \multirow{2}{*}{ Malo } & $\mathrm{Da}$ & 590 & 6,75 & 0,76 & 5,25 & 8,24 & \multirow{2}{*}{3,29} & \multirow{2}{*}{0,0010} \\
\hline & & $\mathrm{Ne}$ & 592 & 3,90 & 0,41 & 3,10 & 4,70 & & \\
\hline & \multirow{2}{*}{ Srednje } & $\mathrm{Da}$ & 31 & 86,05 & 10,35 & 65,74 & 106,37 & \multirow{2}{*}{0,43} & \multirow{2}{*}{0,6676} \\
\hline & & $\mathrm{Ne}$ & 13 & 74,38 & 25,11 & 25,11 & 123,65 & & \\
\hline & \multirow{2}{*}{ Veliko } & $\mathrm{Da}$ & 12 & 532,30 & 168,31 & 202,10 & 862,50 & \multirow{2}{*}{0,95} & \multirow{2}{*}{0,3440} \\
\hline & & $\mathrm{Ne}$ & 1 & 149,00 & 0,00 & 149,00 & 149,00 & & \\
\hline & \multirow{2}{*}{ Ukupno } & $\mathrm{Da}$ & 633 & 18,47 & 2,92 & 12,73 & 24,20 & \multirow{2}{*}{4,25} & \multirow{2}{*}{$<, 0001$} \\
\hline & & $\mathrm{Ne}$ & 606 & 5,37 & 0,69 & 4,02 & 6,72 & & \\
\hline \multirow{10}{*}{$\begin{array}{l}\text { Glavna } \\
\text { djelatnost } \\
\text { poduzeća }\end{array}$} & \multirow{2}{*}{ Industrijska } & $\mathrm{Da}$ & 181 & 34,26 & 11,12 & 12,44 & 56,09 & \multirow{2}{*}{2,28} & \multirow{2}{*}{0,0228} \\
\hline & & $\mathrm{Ne}$ & 164 & 8,41 & 2,20 & 4,09 & 12,72 & & \\
\hline & \multirow{2}{*}{ Trgovinska } & $\mathrm{Da}$ & 142 & 24,12 & 11,10 & 2,34 & 45,90 & \multirow{2}{*}{1,48} & \multirow{2}{*}{0,1403} \\
\hline & & $\mathrm{Ne}$ & 126 & 7,55 & 1,68 & 4,26 & 10,85 & & \\
\hline & \multirow{2}{*}{ Uslužna } & $\mathrm{Da}$ & 284 & 11,75 & 3,26 & 5,35 & 18,16 & \multirow{2}{*}{2,45} & \multirow{2}{*}{0,0146} \\
\hline & & $\mathrm{Ne}$ & 298 & 3,52 & 0,81 & 1,94 & 5,11 & & \\
\hline & \multirow{2}{*}{ Ostalo } & $\mathrm{Da}$ & 26 & 2,73 & 1,13 & 0,51 & 4,95 & \multirow{2}{*}{0,24} & \multirow{2}{*}{0,8100} \\
\hline & & $\mathrm{Ne}$ & 18 & 2,38 & 0,93 & 0,56 & 4,20 & & \\
\hline & \multirow{2}{*}{ Ukupno } & $\mathrm{Da}$ & 633 & 21,52 & 4,65 & 12,40 & 30,64 & \multirow{2}{*}{3,30} & \multirow{2}{*}{0,0010} \\
\hline & & $\mathrm{Ne}$ & 606 & 5,90 & 0,84 & 4,25 & 7,55 & & \\
\hline \multirow{8}{*}{$\begin{array}{l}\text { Lokacija } \\
\text { poduzeća }\end{array}$} & \multirow{2}{*}{$\begin{array}{l}\text { Sjevero- } \\
\text { zapadna } \\
\text { Hrvatska }\end{array}$} & $\mathrm{Da}$ & 325 & 30,63 & 8,24 & 14,47 & 46,79 & & \\
\hline & & $\mathrm{Ne}$ & 304 & 6,17 & 1,08 & 4,05 & 8,29 & 2,94 & 0,0033 \\
\hline & Središnja & $\mathrm{Da}$ & 93 & 8,89 & 1,64 & 5,67 & 12,10 & & \\
\hline & $\begin{array}{l}\text { i Istočna } \\
\text { Hrvatska }\end{array}$ & $\mathrm{Ne}$ & 81 & 3,90 & 0,78 & 2,38 & 5,42 & 2,75 & 0,0060 \\
\hline & Jadranska & $\mathrm{Da}$ & 215 & 10,49 & 1,96 & 6,65 & 14,33 & 195 & 00518 \\
\hline & Hrvatska & $\mathrm{Ne}$ & 221 & 5,57 & 1,59 & 2,44 & 8,70 & & \\
\hline & & $\mathrm{Da}$ & 633 & 19,40 & 3,85 & 11,85 & 26,95 & 352 & 00005 \\
\hline & Uкирпо & $\mathrm{Ne}$ & 606 & 5,57 & 0,80 & 4,00 & 7,14 & J,כ2 & \\
\hline
\end{tabular}

Napomena: p vrijednost je dana za dvosmjeran test. Izvor: izrada autora. 
Prema rezultatima iz tablice 7. moguće je zaključiti da postoji statistički značajna razlika, na svim uobičajeno korištenim razinama signifikantnosti, u ostvarenim prosječnim vrijednostima poslovnih prihoda između poduzeća koja primjenjuju statističke metode u svojem poslovanju i onih poduzeća koja ne primjenjuju statističke metode. Navedeni zaključak se donosi kada se poduzeća promatraju zajedno i to kod svih triju promatranih stratifikacija (veličina poduzeća $-\mathrm{t}$ vrijednost $=4,25$, p vrijednost $<0,0001$; glavna djelatnost poduzeća $-\mathrm{t}$ vrijednost $=3,30, \mathrm{p}$ vrijednost $=0,0010$; lokacija poduzeća $-\mathrm{t}$ vrijednost $=$ $3,52$, p vrijednost $=0,0005)$. Potrebno je istaknuti da se rezultati provedenih statističkih testova hipoteze o jednakosti aritmetičkih sredina ovisno o promatranoj stratifikaciji ponešto razlikuju, a razlog tome leži u korištenju različitih vrijednosti pondera.

Ako se promatraju pojedinačni stratumi poduzeća, vidi se da razlika u ostvarenim prosječnim poslovnim prihodima u 2016. godini između poduzeća koja primjenjuju statističke metode i koja ih ne primjenjuju nije statistički značajna u svim slučajevima. Tako kod stratifikacije prema veličini poduzeća, razlika u ostvarenim prosječnim poslovnim prihodima u 2016. godini između poduzeća koja primjenjuju statističke metode i koja ih ne primjenjuju je statistički značajna, na razini signifikantnosti od $1 \%$, samo ako se promatra stratum malih poduzeća ( $\mathrm{t}$ vrijednost $=3,29$, $\mathrm{p}$ vrijednost $=0,0010)$. Kod stratifikacije prema glavnoj djelatnosti poduzeća postoje dva stratuma, industrijska poduzeća $(\mathrm{t}$ vrijednost $=$ $2,28$, p vrijednost $=0,0228)$ i uslužna poduzeća ( $\mathrm{t}$ vrijednost $=2,45$, p vrijednost $=0,0146$ ), kod kojih je razlika u ostvarenim prosječnim poslovnim prihodima u 2016. godini između poduzeća koja primjenjuju statističke metode i koja ih ne primjenjuju na razini signifikantnosti od $5 \%$ statistički značajna. Ako se promatra stratifikacija poduzeća prema njihovoj lokaciji, zaključuje se da kod sva tri stratuma postoji statistički značajna razlika u ostvarenim poslovnim prihodima u 2016. godini između poduzeća koja primjenjuju statističke metode te onih koja ih ne primjenjuju. Ipak, kod stratuma Sjeverozapadna Hrvatska (t vrijednost = 2,94, p vrijednost $=0,0033)$ i stratuma Središnja i Istočna Hrvatska (t vrijednost $=2,75, \mathrm{p}$ vrijednost $=0,0060$ ) navedena razlika je statistički značajna na razini signifikantnosti od 1 $\%$, a kod stratuma Jadranska Hrvatska (t vrijednost $=1,95$, p vrijednost $=0,0518$ ) ta razlika je statistički značajna na razini signifikantnosti od $10 \%$.

Dok su u poslovne prihode uključeni prihodi samo od redovne djelatnosti poduzeća, dobit poduzeća može uključivati i stavke koje ne proizlaze iz redovne djelatnosti poduzeća odnosno stavke na koje primjena statističkih metoda definitivno nema nikakvih utjecaja. Dobit poduzeća tako može uključivati promjene nastale zbog određenih financijskih i izvanrednih aktivnosti poduzeća. Zbog takvih aktivnosti, dobit poduzeća može biti prikazana u nerealnom iznosu bilo kao velika ili kao jako mala vrijednost. Usporedbom ostvarenih neto dobiti poduzeća u uzorku ustanovljeno je da postoji veliki raspon varijacije između najvećih ostvarenih neto dobiti poduzeća i onih najmanjih. Pomnijom analizom utvrđeno je da postoje određene vrijednosti neto dobiti koje značajnije odstupaju od preostalih vrijednosti. Kako bi se umanjio utjecaj tih netipičnih vrijednosti na rezultate statističke analize te ujedno izostavile iz analize nerealno visoke te nerealno niske vrijednosti neto dobiti, odlučeno je da će se iz analize izostaviti $1 \%$ poduzeća s najvećim vrijednostima neto dobiti te $1 \%$ poduzeća s najmanjim vrijednostima neto dobiti. Na taj način iz daljnje analize izostavljeno je 12 poduzeća s najvećim te 12 poduzeća s najmanjima vrijednostima neto dobiti. U tablici 8. dani su rezultati provedene usporedbe ostvarenih prosječnih neto dobiti u 2016. godini između poduzeća koja primjenjuju statističke metode u svojem poslovanju te onih koja ih ne primjenjuju. 
Tablica 8: Primjena statističkih metoda i poslovni rezultati poduzeća iz Hrvatske, neto dobit poduzeća u 2016. godini, u milijunima kuna, $\mathrm{n}=1217$

\begin{tabular}{|c|c|c|c|c|c|c|c|c|c|}
\hline Stratif. & Stratum & $\begin{array}{l}\text { Primjena } \\
\text { stat. } \\
\text { metoda }\end{array}$ & $\begin{array}{c}\text { Vel. } \\
\text { uzorka }\end{array}$ & $\begin{array}{l}\text { Arit. } \\
\text { sredina }\end{array}$ & $\begin{array}{l}\text { Stand. } \\
\text { pog. } \\
\text { procjene } \\
\text { arit. sred. }\end{array}$ & $\begin{array}{r}95 \% \\
\text { pouzd } \\
\text { ari }\end{array}$ & $\begin{array}{l}\text { terval } \\
\text { ocjene } \\
\text { red. }\end{array}$ & $\begin{array}{c}\mathrm{t} \\
\text { vrijed. }\end{array}$ & $\underset{\text { vrijed. }}{p}$ \\
\hline \multirow{8}{*}{$\begin{array}{l}\text { Veličina } \\
\text { poduzeća }\end{array}$} & \multirow{2}{*}{ Malo } & $\mathrm{Da}$ & 582 & 0,31 & 0,04 & 0,23 & 0,38 & \multirow{2}{*}{1,27} & \multirow{2}{*}{0,2038} \\
\hline & & $\mathrm{Ne}$ & 592 & 0,24 & 0,03 & 0,18 & 0,31 & & \\
\hline & \multirow{2}{*}{ Srednje } & $\mathrm{Da}$ & 26 & 1,92 & 0,63 & 0,68 & 3,16 & \multirow{2}{*}{1,13} & \multirow{2}{*}{0,2587} \\
\hline & & $\mathrm{Ne}$ & 10 & 0,84 & 0,72 & $-0,57$ & 2,25 & & \\
\hline & \multirow{2}{*}{ Veliko } & $\mathrm{Da}$ & 6 & 4,82 & 1,54 & 1,80 & 7,84 & \multirow{2}{*}{0,55} & \multirow{2}{*}{0,5799} \\
\hline & & $\mathrm{Ne}$ & 1 & 3,83 & 0,00 & 3,83 & 3,83 & & \\
\hline & \multirow{2}{*}{ Ukupno } & $\mathrm{Da}$ & 614 & 0,44 & 0,05 & 0,34 & 0,55 & \multirow{2}{*}{2,80} & \multirow{2}{*}{0,0052} \\
\hline & & $\mathrm{Ne}$ & 603 & 0,26 & 0,04 & 0,19 & 0,33 & & \\
\hline \multirow{10}{*}{$\begin{array}{l}\text { Glavna } \\
\text { djelatnost } \\
\text { poduzeća }\end{array}$} & \multirow{2}{*}{ Industrijska } & $\mathrm{Da}$ & 173 & 0,64 & 0,13 & 0,39 & 0,90 & \multirow{2}{*}{1,83} & \multirow{2}{*}{0,0674} \\
\hline & & $\mathrm{Ne}$ & 160 & 0,35 & 0,09 & 0,17 & 0,53 & & \\
\hline & \multirow{2}{*}{ Trgovinska } & $\mathrm{Da}$ & 141 & 0,38 & 0,08 & 0,22 & 0,53 & \multirow{2}{*}{1,28} & \multirow{2}{*}{0,1991} \\
\hline & & $\mathrm{Ne}$ & 126 & 0,24 & 0,06 & 0,12 & 0,37 & & \\
\hline & \multirow{2}{*}{ Uslužna } & $\mathrm{Da}$ & 274 & 0,34 & 0,07 & 0,20 & 0,47 & \multirow{2}{*}{1,42} & \multirow{2}{*}{0,1570} \\
\hline & & $\mathrm{Ne}$ & 299 & 0,22 & 0,04 & 0,14 & 0,31 & & \\
\hline & \multirow{2}{*}{ Ostalo } & $\mathrm{Da}$ & 26 & 0,02 & 0,09 & $-0,17$ & 0,20 & \multirow{2}{*}{$-0,74$} & \multirow{2}{*}{0,4593} \\
\hline & & $\mathrm{Ne}$ & 18 & 0,10 & 0,07 & $-0,03$ & 0,23 & & \\
\hline & \multirow{2}{*}{ Ukupno } & $\mathrm{Da}$ & 614 & 0,43 & 0,05 & 0,33 & 0,53 & \multirow{2}{*}{2,60} & \multirow{2}{*}{0,0093} \\
\hline & & $\mathrm{Ne}$ & 603 & 0,26 & 0,04 & 0,19 & 0,33 & & \\
\hline \multirow{8}{*}{$\begin{array}{l}\text { Lokacija } \\
\text { poduzeća }\end{array}$} & \multirow{2}{*}{\begin{tabular}{|l} 
Sjevero- \\
zapadna \\
Hrvatska \\
\end{tabular}} & $\mathrm{Da}$ & 312 & 0,46 & 0,08 & 0,32 & 0,61 & & \\
\hline & & $\mathrm{Ne}$ & 302 & 0,25 & 0,05 & 0,15 & 0,34 & 2,44 & 0,0150 \\
\hline & Središnja & $\mathrm{Da}$ & 93 & 0,44 & 0,16 & 0,13 & 0,75 & & \\
\hline & \begin{tabular}{|l} 
i Istočna \\
Hrvatska
\end{tabular} & $\mathrm{Ne}$ & 81 & 0,22 & 0,06 & 0,11 & 0,34 & 1,28 & 0,2016 \\
\hline & Jadranska & $\mathrm{Da}$ & 209 & 0,34 & 0,07 & 0,20 & 0,49 & 0.57 & 0.5713 \\
\hline & Hrvatska & $\mathrm{Ne}$ & 220 & 0,29 & 0,07 & 0,15 & 0,42 & $0,5 /$ & $0,0 / 13$ \\
\hline & & $\mathrm{Da}$ & 614 & 0,41 & 0,05 & 0,31 & 0,52 & 249 & 00128 \\
\hline & Окирло & $\mathrm{Ne}$ & 603 & 0,26 & 0,04 & 0,19 & 0,33 & 2,49 & 0,0120 \\
\hline
\end{tabular}

Napomena: p vrijednost je dana za dvosmjeran test.

Izvor: izrada autora.

Provedeni statistički testovi hipoteze o razlici aritmetičkih sredina, čiji su rezultati prikazani u tablici 8., pokazuju da, na razini značajnosti od $5 \%$, postoji statistički značajna razlika u prosječnoj vrijednosti ostvarene neto dobiti u 2016. godini između poduzeća koja primjenjuju statističke metode i poduzeća koja ih ne primjenjuju. Zbog utjecaja pondera vrijednosti pojedinih statističkih kategorija se razlikuju, ali kada se promatraju sva poduzeća u cjelini kod sve tri provedene stratifikacije donosi se navedeni zaključak Ipak, kada se usporedba spusti na razinu stratuma, zaključci se izrazito mijenjaju. Tako ako se poduzeća promatraju prema veličini, niti kod jednog od tri promatrana stratuma razlika u prosječnoj 
vrijednosti ostvarene neto dobiti u 2016. godini između poduzeća koja primjenjuju statističke metode i poduzeća koja ih ne primjenjuju nije statistički značajna. Kod stratifikacije poduzeća prema glavnoj djelatnosti poduzeća razlika u prosječnoj vrijednosti ostvarene neto dobiti u 2016. godini između poduzeća koja primjenjuju statističke metode i poduzeća koja ih ne primjenjuju je statistički značajna samo kod industrijskih poduzeća (t vrijednost $=1,83$, p vrijednost $=0,0674$ ) i to tek na razini signifikantnosti od $10 \%$. Slično, kada se promatra stratifikacija poduzeća prema lokaciji, samo kod stratuma Sjeverozapadna Hrvatska ( $\mathrm{t}$ vrijednost $=2,44, \mathrm{p}$ vrijednost $=0,0150$ ), na razini signifikantnosti od $5 \%$, uočava se statistički značajna razlika u prosječnoj vrijednosti ostvarene neto dobiti u 2016. godini između poduzeća koja primjenjuju statističke metode i poduzeća koja ih ne primjenjuju.

Pokazalo se, dakle, da poduzeća koja primjenjuju statističke metode, u cjelini gledano, ostvaruju u prosjeku veću vrijednost neto dobiti u odnosu na poduzeća koja te metode ne primjenjuju. Potrebno je naglasiti da je riječ o prosjeku, što znači da zaključak nije da poduzeće koje primjenjuje statističke metode mora nužno ostvarivati veću dobit u odnosu na neko poduzeće koje statističke metode ne primjenjuje. Međutim, primjena statističkih metoda mogla bi povećati šanse odnosno vjerojatnost ostvarivanja veće neto dobiti. Kako bi se to ispitalo provedena je logistička regresija u kojoj ulogu zavisne varijable ima neto dobit iz 2016. godine. Međutim, za potrebe logističke regresije ta varijabla je definirana kao binarna odnosno indikator varijabla s modalitetima 1 ako je poduzeće ostvarilo pozitivnu neto dobit, dok u ostalim slučajevima ta varijabla poprima vrijednost nula. U tablici 9. prikazani su rezultati dobivenih logističkih regresijskih modela u kojima se promatrao samo utjecaj primjene statističkih metoda (modeli oznake A) ili se tom utjecaju pridodao i utjecaj stratuma kroz dodatne binarne varijable (modeli oznake B). Prilikom procjene parametara u logističkim regresijskim modelima primijenjena je metoda najveće vjerodostojnosti.

Ako se promatraju samo logistički regresijski modeli oznake A, u kojima se kao nezavisna varijabla nalazi samo binarna odnosno indikator varijabla primjena statističkih metoda, zaključuje se da su navedeni modeli statistički značajni na razini od $10 \%$, kada se promatra stratifikacija poduzeća prema veličini (Wald hi-kvadrat $=2,8140$, $\mathrm{p}$ vrijednost $=0,0934$ ) te prema glavnoj djelatnosti (Wald hi-kvadrat $=2,9321, \mathrm{p}$ vrijednost $=0,0868$ ) odnosno na razini od $15 \%$, ako se promatra stratifikacija poduzeća prema lokaciji (Wald hi-kvadrat $=2,2685$, p vrijednost $=0,1320$ ). Procjene omjera vjerojatnosti otkrivaju da, ako se promatra stratifikacija poduzeća prema njihovoj veličini, poduzeća koja primjenjuju statističke metode imaju 30,9 \% veću šansu ostvarivanja pozitivne neto dobiti u odnosu na poduzeća koja ih ne primjenjuju. Poduzeća koja primjenjuju statističke metode imaju 31,9 $\%$, ako se promatra stratifikacija prema glavnoj djelatnosti poduzeća odnosno $27,6 \%$, ako se promatra stratifikacija poduzeća prema lokaciji, veće šanse ostvarivanja neto dobiti u odnosu na poduzeća koja statističke metode ne primjenjuju. Shodno tome, druga istraživačka hipoteza, da poduzeća iz Hrvatske koja primjenjuju statističke metode imaju statistički značajno veće šanse ostvarivanja pozitivne neto dobiti u odnosu na poduzeća koja ih ne primjenjuju, se može prihvatiti.

Dodatno uvrštavanje stratuma u logističke regresijske modele kao dodatne nezavisne varijable u obliku binarnih varijabli, modeli oznake $B$, je pokazalo da su vjerojatnosti ostvarivanja pozitivne neto dobiti podjednake između stratuma unutar pojedine stratifikacije. Jedino se u modelu B, kada se promatra stratifikacija prema djelatnosti poduzeća, pokazalo da postoji statistički značajna nejednakost $u$ ostvarivanju pozitivne neto dobiti između raz- 
ličitih stratuma. Tako, na razini signifikantnosti od $5 \%$, industrijska poduzeća imaju 9,9\% veće šanse ostvarivanja pozitivne neto dobiti ako primjenjuju statističke metode u odnosu na uslužna poduzeća. S druge strane, na razini signifikantnosti od $5 \%$, ostala poduzeća imaju $65 \%$ manje šanse ostvarivanja pozitivne neto dobiti ako primjenjuju statističke metode u odnosu na uslužna poduzeća.

Tablica 9: Primjena statističkih metoda i poslovni rezultati poduzeća iz Hrvatske, neto dobit poduzeća u 2016. godini, logistička regresija, $n=1217$

\begin{tabular}{|c|c|c|c|c|c|c|c|c|c|}
\hline \multirow[b]{2}{*}{ Stratif. } & \multirow[b]{2}{*}{ Model } & \multirow[b]{2}{*}{ Varijabla } & \multicolumn{4}{|c|}{$\begin{array}{l}\text { Analiza procjene metodom najveće } \\
\text { vjerodostojnosti }\end{array}$} & \multicolumn{3}{|c|}{$\begin{array}{c}\text { Procjene omjera } \\
\text { vjerojatnosti }\end{array}$} \\
\hline & & & Procjena & $\begin{array}{l}\text { Stand. } \\
\text { pogr. }\end{array}$ & $\begin{array}{l}\text { Wald hi- } \\
\text { kvadrat }\end{array}$ & $\begin{array}{c}\mathbf{p} \\
\text { vrijed. }\end{array}$ & \begin{tabular}{l|} 
Procj. \\
jednim \\
brojem
\end{tabular} & $\begin{array}{r}90 \% \\
\text { interva }\end{array}$ & $\begin{array}{l}\text { Wald } \\
\text { pouzd. }\end{array}$ \\
\hline \multirow{6}{*}{$\begin{array}{l}\text { Veličina } \\
\text { poduzeća }\end{array}$} & \multirow{2}{*}{ A } & Konstanta & 1,7272 & 0,0802 & 463,2854 & $<, 0001$ & --- & --- & --- \\
\hline & & Pr. st. met. & 0,1347 & 0,0803 & 2,8140 & 0,0934 & 1,309 & 1,005 & 1,705 \\
\hline & \multirow{4}{*}{ B } & Konstanta & 5,9960 & 11,6944 & 0,2629 & 0,6081 & --- & --- & --- \\
\hline & & Pr. st. met. & 0,1330 & 0,0811 & 2,6933 & 0,1008 & 1,305 & 0,999 & 1,703 \\
\hline & & S.-Malo & $-4,2668$ & 11,6945 & 0,1331 & 0,7152 & $<0,001$ & $<0,001$ & $>999,999$ \\
\hline & & S.-Srednje & $-4,6294$ & 11,6659 & 0,1575 & 0,6915 & $<0,001$ & $<0,001$ & $>999,999$ \\
\hline \multirow{7}{*}{$\begin{array}{l}\text { Glavna } \\
\text { djelatnost } \\
\text { poduzeća }\end{array}$} & \multirow{2}{*}{ A } & Konstanta & 1,7267 & 0,0807 & 458,1446 & $<, 0001$ & --- & --- & --- \\
\hline & & Pr. st. met. & 0,1386 & 0,0809 & 2,9321 & 0,0868 & 1,319 & 1,011 & 1,722 \\
\hline & \multirow{5}{*}{ B } & Konstanta & 1,5088 & 0,1062 & 202,0103 & $<, 0001$ & --- & --- & --- \\
\hline & & Pr. st. met. & 0,1486 & 0,0818 & 3,3018 & 0,0692 & 1,346 & 1,029 & 1,761 \\
\hline & & S.-Industr. & 0,3757 & 0,1562 & 5,7845 & 0,0162 & 1,099 & 0,789 & 1,531 \\
\hline & & S.-Trgov. & 0,1132 & 0,1580 & 0,5131 & 0,4738 & 0,845 & 0,604 & 1,183 \\
\hline & & S.-Ostala & $-0,7699$ & 0,2595 & 8,8040 & 0,0030 & 0,350 & 0,195 & 0,628 \\
\hline \multirow{6}{*}{$\begin{array}{l}\text { Lokacija } \\
\text { poduzeća }\end{array}$} & \multirow{2}{*}{ A } & Konstanta & 1,7229 & 0,0808 & 454,1742 & $<, 0001$ & --- & --- & --- \\
\hline & & Pr. st. met. & 0,1217 & 0,0808 & 2,2685 & 0,1320 & 1,276 & 0,978 & 1,664 \\
\hline & \multirow{4}{*}{ B } & Konstanta & 1,7428 & 0,0949 & 337,0261 & $<, 0001$ & --- & --- & --- \\
\hline & & Pr. st. met. & 0,1198 & 0,0811 & 2,1858 & 0,1393 & 1,271 & 0,973 & 1,659 \\
\hline & & S.-Sjev. H. & $-0,0038$ & 0,1149 & 0,0011 & 0,9734 & 0,913 & 0,604 & 1,380 \\
\hline & & S.-Jadr. H. & $-0,0829$ & 0,1215 & 0,4648 & 0,4954 & 0,844 & 0,550 & 1,295 \\
\hline
\end{tabular}

Napomena: referentne kategorije za kategorijske varijable su poduzeće ne koristi statističke metode te ovisno o promatranoj stratifikaciji veliko poduzeće, uslužno poduzeće odnosno Središnja i Istočna (Panonska) Hrvatska.

S. - stratum

Izvor: izrada autora.

\subsection{Učestalost primjene statističkih metoda i poslovni rezultati poduzeća}

U nastavku analize promatrat će se imaju li duljina te učestalost primjene statističkih metoda statistički značajni utjecaj na poslovne rezultate poduzeća. Budući da će se u tim analizama promatrati samo ona poduzeća koja primjenjuju statističke metode, broj promatranih poduzeća će biti manji nego u prijašnjim analizama. Dodatno, budući da je varijabla od interesa neto dobit, broj poduzeća će se dodatno umanjiti izostavljanjem iz analize po- 
duzeća koja spadaju u $1 \%$ poduzeća s ostvarenom najvišom neto dobiti u 2016. godini te 1 $\%$ poduzeća koja imaju najnižu ostvarenu neto dobit te godine.

Tablica 10: Duljina primjene statističkih metoda (u godinama) i poslovni rezultati poduzeća iz Hrvatske, neto dobit poduzeća u 2016. godini, u tisućama kunama, linearna regresija, $n=430$

\begin{tabular}{|c|c|c|c|c|c|c|}
\hline Stratif. & Stratum & Varijabla & Procjena & $\begin{array}{c}\text { Stand. } \\
\text { pogreška }\end{array}$ & t vrijed. & p vrijed. \\
\hline \multirow{12}{*}{$\begin{array}{l}\text { Veličina } \\
\text { poduzeća }\end{array}$} & \multirow[b]{2}{*}{ Malo } & Konstanta & 479,34 & 203,42 & 2,36 & 0,0189 \\
\hline & & $\begin{array}{l}\text { Duljina prim. stat. } \\
\text { metoda }\end{array}$ & $-7,55$ & 8,92 & $-0,85$ & 0,3981 \\
\hline & \multirow[b]{2}{*}{ Srednje } & Konstanta & $7.117,13$ & $4.552,74$ & 1,56 & 0,1187 \\
\hline & & $\begin{array}{l}\text { Duljina prim. stat. } \\
\text { metoda }\end{array}$ & $-181,60$ & 244,21 & $-0,74$ & 0,4575 \\
\hline & \multirow[b]{2}{*}{ Veliko } & Konstanta & $17.590,68$ & $11.623,66$ & 1,51 & 0,1309 \\
\hline & & $\begin{array}{l}\text { Duljina prim. stat. } \\
\text { metoda }\end{array}$ & $-499,24$ & 725,61 & $-0,69$ & 0,4918 \\
\hline & \multirow[b]{2}{*}{ Ukupno } & Konstanta & 644,63 & 216,09 & 2,98 & 0,0030 \\
\hline & & $\begin{array}{l}\text { Duljina prim. stat. } \\
\text { metoda }\end{array}$ & $-4,93$ & 9,72 & $-0,51$ & 0,6124 \\
\hline & \multirow{4}{*}{$\begin{array}{l}\text { Ukupno s } \\
\text { indikator } \\
\text { varijablama }\end{array}$} & Konstanta & $8.531,99$ & $2.547,39$ & 3,35 & 0,0009 \\
\hline & & $\begin{array}{l}\text { Duljina prim. stat. } \\
\text { metoda }\end{array}$ & $-12,87$ & 9,99 & $-1,29$ & 0,1987 \\
\hline & & Mala poduzeća & $-7.991,68$ & $2.529,46$ & $-3,16$ & 0,0017 \\
\hline & & $\begin{array}{l}\text { Srednje velika } \\
\text { poduzeća }\end{array}$ & $-3.793,25$ & $2.976,48$ & $-1,27$ & 0,2032 \\
\hline \multirow{15}{*}{$\begin{array}{l}\text { Glavna } \\
\text { djelatnost } \\
\text { poduzeća }\end{array}$} & \multirow[b]{2}{*}{ Industrijska } & Konstanta & $1.151,63$ & 438,39 & 2,63 & 0,0089 \\
\hline & & $\begin{array}{l}\text { Duljina prim. stat. } \\
\text { metoda }\end{array}$ & $-6,69$ & 18,76 & $-0,36$ & 0,7217 \\
\hline & \multirow[b]{2}{*}{ Trgovinska } & Konstanta & 650,17 & 337,11 & 1,93 & 0,0544 \\
\hline & & $\begin{array}{l}\text { Duljina prim. stat. } \\
\text { metoda }\end{array}$ & $-3,78$ & 11,32 & $-0,33$ & 0,7384 \\
\hline & \multirow[b]{2}{*}{ Uslužna } & Konstanta & 684,38 & 466,21 & 1,47 & 0,1429 \\
\hline & & $\begin{array}{l}\text { Duljina prim. stat. } \\
\text { metoda }\end{array}$ & $-1,15$ & 24,85 & $-0,05$ & 0,9632 \\
\hline & \multirow[b]{2}{*}{ Ostalo } & Konstanta & 118,77 & 148,53 & 0,80 & 0,4244 \\
\hline & & $\begin{array}{l}\text { Duljina prim. stat. } \\
\text { metoda }\end{array}$ & $-22,54$ & 30,28 & $-0,74$ & 0,4572 \\
\hline & \multirow[b]{2}{*}{ Ukupno } & Konstanta & 785,72 & 245,66 & 3,20 & 0,0015 \\
\hline & & $\begin{array}{l}\text { Duljina prim. stat. } \\
\text { metoda }\end{array}$ & $-3,11$ & 11,13 & $-0,28$ & 0,7800 \\
\hline & \multirow{5}{*}{$\begin{array}{l}\text { Ukupno s } \\
\text { indikator } \\
\text { varijablama }\end{array}$} & Konstanta & 715,78 & 324,84 & 2,20 & 0,0281 \\
\hline & & $\begin{array}{l}\text { Duljina prim. stat. } \\
\text { metoda }\end{array}$ & $-4,06$ & 10,95 & $-0,37$ & 0,7112 \\
\hline & & Industrijska poduzeća & 404,01 & 391,01 & 1,03 & 0,3021 \\
\hline & & Trgovinska poduzeća & $-61,80$ & 337,01 & $-0,18$ & 0,8546 \\
\hline & & Ostala poduzeća & $-738,04$ & 289,15 & $-2,55$ & 0,0110 \\
\hline
\end{tabular}


Nastavak tablice 10.

\begin{tabular}{|c|c|c|c|c|c|c|}
\hline Stratif. & Stratum & Varijabla & Procjena & $\begin{array}{c}\text { Stand. } \\
\text { pogreška }\end{array}$ & $\mathrm{t}$ vrijed. & p vrijed. \\
\hline \multirow{12}{*}{$\begin{array}{l}\text { Lokacija } \\
\text { poduzeća }\end{array}$} & \multirow{2}{*}{$\begin{array}{l}\text { Sjeverozapadna } \\
\text { Hrvatska }\end{array}$} & Konstanta & 623,14 & 217,59 & 2,86 & 0,0044 \\
\hline & & $\begin{array}{l}\text { Duljina prim. stat. } \\
\text { metoda }\end{array}$ & 11,70 & 13,42 & 0,87 & 0,3840 \\
\hline & \multirow{2}{*}{$\begin{array}{l}\text { Središnja i } \\
\text { Istočna Hrvat. }\end{array}$} & Konstanta & 697,66 & 564,80 & 1,24 & 0,2174 \\
\hline & & $\begin{array}{l}\text { Duljina prim. stat. } \\
\text { metoda }\end{array}$ & $-19,43$ & 36,99 & $-0,53$ & 0,5997 \\
\hline & \multirow[b]{2}{*}{$\begin{array}{l}\text { Jadranska } \\
\text { Hrvatska }\end{array}$} & Konstanta & $1.113,78$ & 660,00 & 1,69 & 0,0922 \\
\hline & & $\begin{array}{l}\text { Duljina prim. stat. } \\
\text { metoda }\end{array}$ & $-24,87$ & 32,12 & $-0,77$ & 0,4391 \\
\hline & \multirow[b]{2}{*}{ Ukupno } & Konstanta & 791,25 & 268,51 & 2,95 & 0,0034 \\
\hline & & $\begin{array}{l}\text { Duljina prim. stat. } \\
\text { metoda }\end{array}$ & $-4,40$ & 12,36 & $-0,36$ & 0,7218 \\
\hline & \multirow{4}{*}{$\begin{array}{l}\text { Ukupno s } \\
\text { indikator } \\
\text { varijablama }\end{array}$} & Konstanta & 537,48 & 269,86 & 1,99 & 0,0470 \\
\hline & & $\begin{array}{l}\text { Duljina prim. stat. } \\
\text { metoda }\end{array}$ & $-4,76$ & 12,32 & $-0,39$ & 0,6993 \\
\hline & & $\begin{array}{l}\text { Sjeverozapadna } \\
\text { Hrvatska }\end{array}$ & 283,42 & 273,87 & 1,03 & 0,3013 \\
\hline & & Jadranska Hrvatska & 341,99 & 409,60 & 0,83 & 0,4042 \\
\hline
\end{tabular}

Napomena: referentne kategorije za kategorijske varijable ovisno o promatranoj stratifikaciji su veliko poduzeće, uslužno poduzeće odnosno Središnja i Istočna (Panonska) Hrvatska.

Izvor: izrada autora.

U tablici 10. dani su glavni rezultati dobivenih linearno regresijskih modela u kojima ulogu zavisne varijable ima ostvarena neto dobit poduzeća u 2016. godini, u tisućama kuna, dok ulogu nezavisne varijable ima duljina primjene statističkih metoda, izraženo u godinama. Navedeni linearni regresijski modeli oblikovani su za svaki stratum zasebno te na razini pojedine stratifikacije. Isto tako su kod svake stratifikacije formirani linearni regresijski modeli u kojima su kao nezavisne varijable, u obliku binarnih varijabli, uključeni stratumi u okviru promatrane stratifikacije.

Rezultati iz tablice 10. su pokazali da duljina primjene statističkih metoda, na razini značajnosti od $5 \%$, nema statistički značajan utjecaj na vrijednost neto dobiti u skoro svim slučajevima. Shodno tome, zaključuje se sama činjenica da se statističke metode koriste dulji niz godina u poduzeću nije jamstvo da će to dovesti do povećanja neto dobiti.

Kako bi se ispitalo ima li možda učestalost primjene statističkih metoda utjecaja na promjenu vjerojatnosti ostvarivanja pozitivne neto dobiti, provedena je odgovarajuća logistička regresijska analiza. U logističkim regresijskima modelima zavisna varijabla je definirana kao binarna varijabla koja poprima vrijednost 1 ako je poduzeće ostvarilo pozitivnu neto dobit u 2016. godinu, a inače poprima vrijednost 0 . U logističke regresijske modele je kao nezavisna varijabla korištena učestalost primjene statističkih metoda s tri definirane razine (često, rijetko, vrlo rijetko). Rezultati logističkih regresijskih modela prikazani su u tablici 11. 
Tablica 11: Učestalost primjene statističkih metoda i poslovni rezultati poduzeća iz Hrvatske, neto dobit poduzeća u 2016. godini, logistička regresija, $n=322$

\begin{tabular}{|c|c|c|c|c|c|c|c|c|}
\hline \multirow[b]{2}{*}{ Stratif. } & \multirow[b]{2}{*}{ Varijabla } & \multicolumn{4}{|c|}{$\begin{array}{l}\text { Analiza procjene metodom najveće } \\
\text { vjerodostojnosti }\end{array}$} & \multicolumn{3}{|c|}{$\begin{array}{l}\text { Procjene omjera } \\
\text { vjerojatnosti }\end{array}$} \\
\hline & & Procjena & $\begin{array}{c}\text { Stand. } \\
\text { pogreška }\end{array}$ & $\begin{array}{l}\text { Wald hi- } \\
\text { kvadrat }\end{array}$ & $\begin{array}{c}p \\
\text { vrijed. }\end{array}$ & $\begin{array}{c}\text { Procjena } \\
\text { jednim } \\
\text { brojem }\end{array}$ & $\begin{array}{r}90 \% \\
\text { interva }\end{array}$ & $\begin{array}{l}\text { Wald } \\
\text { I pouzd. }\end{array}$ \\
\hline \multirow{3}{*}{$\begin{array}{l}\text { Bez } \\
\text { stratifik. }\end{array}$} & Konstanta & $-1,7220$ & 0,2008 & 73,5789 & $<, 0001$ & --- & --- & --- \\
\hline & Uč. - Rijetko & $-0,0698$ & 0,2568 & 0,0738 & 0,7859 & 0,861 & 0,345 & 2,151 \\
\hline & Uč. - Vrlo rijetko & $-0,0100$ & 0,2408 & 0,0017 & 0,9668 & 0,914 & 0,379 & 2,202 \\
\hline \multirow{5}{*}{$\begin{array}{l}\text { Veličina } \\
\text { poduzeća }\end{array}$} & Konstanta & 11,9311 & 13,9314 & 0,7335 & 0,3918 & --- & --- & -- \\
\hline & Uč. - Rijetko & 0,0698 & 0,2568 & 0,0738 & 0,7859 & 1,161 & 0,465 & 2,900 \\
\hline & $\begin{array}{l}\text { Uč. - Vrloa } \\
\text { rijetko }\end{array}$ & 0,0100 & 0,2408 & 0,0017 & 0,9668 & 1,094 & 0,454 & 2,635 \\
\hline & Str. - Malo pod. & $-10,2091$ & 13,8798 & 0,5410 & 0,4620 & $<0,001$ & $<0,001$ & $>999,999$ \\
\hline & $\begin{array}{l}\text { Str. - Srednje } \\
\text { pod. }\end{array}$ & 5,0895 & 6,9412 & 0,5376 & 0,4634 & 0,970 & 0,713 & 1,321 \\
\hline \multirow{6}{*}{$\begin{array}{l}\text { Glavna } \\
\text { djelatnost } \\
\text { poduzeća }\end{array}$} & Konstanta & 1,6180 & 0,2434 & 44,2053 & $<, 0001$ & --- & --- & -- \\
\hline & Uč. - Rijetko & 0,0043 & 0,2623 & 0,0003 & 0,9871 & 1,097 & 0,429 & 2,804 \\
\hline & Uč. - Vrlo rijetko & 0,0844 & 0,2447 & 0,1188 & 0,7303 & 1,189 & 0,484 & 2,921 \\
\hline & $\begin{array}{l}\text { Str. - Industr. } \\
\text { pod. }\end{array}$ & 0,4755 & 0,3274 & 2,1096 & 0,1464 & 1,340 & 0,663 & 2,708 \\
\hline & Str. - Trgov. pod. & & & & 0,9980 & 0,832 & 0,414 & 1,676 \\
\hline & Str - Ostala pod. & $-0,6573$ & 0,4996 & 1,7311 & 0,1883 & 0,432 & 0,139 & 1,338 \\
\hline \multirow{5}{*}{$\begin{array}{l}\text { Lokacija } \\
\text { poduzeća }\end{array}$} & Konstanta & 1,8426 & 0,2412 & 58,3459 & $<, 0001$ & --- & --- & -- \\
\hline & Uč. - Rijetko & 0,0506 & 0,2679 & 0,0357 & 0,8501 & 1,103 & 0,433 & 2,810 \\
\hline & Uč. - Vrlo rijetko & $-0,0033$ & 0,2453 & 0,0002 & 0,9893 & 1,045 & 0,432 & 2,528 \\
\hline & Str. - Sjev. Hrvat. & 0,0535 & 0,2502 & 0,0457 & 0,8307 & 0,880 & 0,338 & 2,287 \\
\hline & Str. - Jadr. Hrvat. & $-0,2353$ & 0,2662 & 0,7815 & 0,3767 & 0,659 & 0,245 & 1,773 \\
\hline
\end{tabular}

Napomena: referentne kategorije za kategorijske varijable su poduzeće često koristi statističke metode te, ovisno o promatranoj stratifikaciji, veliko poduzeće, uslužno poduzeće ili Središnja i Istočna (Panonska) Hrvatska.

Uč. - učestalost, Str. - stratum

Izvor: izrada autora.

Rezultati iz tablice 11. su pokazali da niti učestalost primjene statističkih metoda ne utječe statistički značajno na promjenu vjerojatnosti ostvarivanja pozitivne neto dobiti poduzeća. Navedeni zaključak se donosi kod svih promatranih stratifikacija poduzeća.

\section{ZAKLJUČAK}

Primjena statističkih metoda ima dugu tradiciju. Međutim, poduzeća, iz različitih razloga, još uvijek imaju određenu averziju prema njima i još uvijek teško pronalazi put do primjene u poduzećima. Nažalost, niti poduzeća iz Hrvatske nisu iznimka u tome. Provedeno web anketno istraživanje pokazalo je da je udjel poduzeća koja primjenjuju statističke 
metode, u odnosu na udjel poduzeća koja ih ne primjenjuju, veći jedino kada se promatraju srednje velika te velika poduzeća. Kod svih ostalih promatranih kategorija stratuma udjel poduzeća koja ih ne primjenjuju je veći.

U radu se ispitivao i utjecaj primjene statističkih metoda na poslovne rezultate poduzeća. Tako se pokazalo da postoji statistički značajna razlika u visini ostvarenih prosječnih poslovnih prihoda poduzeća između poduzeća koja primjenjuju statističke metode te onih koja ih ne primjenjuju. Navedena statistički značajna razlika je prisutna kada se promatraju sva poduzeća u cjelini dok spuštanjem na niže razine ta razlika postaje statistički značajna samo kod nekoliko stratuma. Slični zaključci se donose i kada se promatra neto dobit poduzeća. Međutim, ohrabrujući je podatak da, ovisno o promatranoj stratifikaciji, poduzeća koja primjenjuju statističke metode imaju od 27,6 \% do 31,9\% veću šansu ostvarivanja pozitivne neto dobiti u odnosu na poduzeća koja ih ne primjenjuju.

Rezultati provedenih analiza su isto tako pokazali da niti duljina primjene statističkih metoda niti učestalost njihove primjene ne utječe statistički značajno na povećanje vrijednosti neto dobiti poduzeća. Iz navedenoga se može zaključiti da se poduzeće ne bi trebalo zadovoljiti s time da samo primjenjuje statističke metode već bi se trebala obratiti pozornost na kvalitetu njihove primjene. Drugim riječima, više pozornosti bi se trebalo dati prepoznavanju situacija kada bi se statističke metode mogle primijeniti te bi trebalo obratiti pozornost prema korištenju odgovarajućih statističkih metoda te ispravnom interpretiranju dobivenih rezultata. Ključ uspjeha stoga leži u obrazovanim radnicima koji su upoznati s mogućnostima primjene statističkih metoda te prednostima i nedostacima pojedine metode. Dakako, dobivene rezultate treba tumačiti u kontekstu promatranja izoliranog utjecaja primjene statističkih metoda na uspješnost poslovanja. Za potpuno razumijevanje dobivenih rezultata trebalo bi u analizu uključiti i ostale unutarnje te vanjske čimbenike uspješnosti poslovanja.

U budućim istraživanjima potrebno je ispitati koliko su zaposleni zaista upoznati sa statističkim metodama i koristima njihove primjene. Isto tako, potrebno je ispitati stav poslodavaca prema statističkim metodama te koliko su oni spremni ulagati u njihovu primjenu.

\section{Napomena}

Ovaj rad je podržan od strane Hrvatske zaklade za znanost kao dio znanstvenog projekta „Statistical Modelling for Response to Crisis and Economic Growth in Western Balkan Countries“ (STRENGTHS) (broj projekta: IP-2013-9402).

\section{LITERATURA:}

1. 1KA (2018), How long should my survey be?, dostupno na: https://www.1ka.si/d/en/ web-surveys/basic-recommendations/how-long-should-my-survey-be (pristupano 16. veljače 2018.).

2. Ben-Zvi, D., Garfield, J., (2004), Statistical Literacy, Reasoning, and Thinking: Goals, Definitions, and Challenges, u: Ben-Zvi, D., Garfield, J., eds, The challenge of developing statistical literacy, reasoning, and thinking, Dordrecht, Kluwer Academic Publishers, pp. 3-16. 
3. Bokan, N., Grgurić, L., Krznar, I., Lang, M., (2009), The Impact of the Financial Crisis and Policy Responses in Croatia, Croatian National Bank Working papers, No. 22, pp. 1-60.

4. Ćurlin, S., (2006.), Primjena metoda predviđanja u strateškom planiranju hrvatskih poduzeća, magistarski rad, Zagreb: Ekonomski fakultet.

5. Dumičić, K., (2004.), Istraživanje implementiranosti sustava kvalitete u hrvatskim poduzećima, Zbornik Ekonomskog fakulteta u Zagrebu, Vol. 2, No. 1, pp. 45-66.

6. Dumičić, K., Bregar, L., Žmuk, B., (2014), Statistical Methods Use in Small Enterprises: Relation to Performance, Business Systems Research Journal, Vol. 5, No. 3, pp. $37-48$.

7. Dumičić, K., Gajdić, D., (2011.), Istraživanje utjecaja primjene sustava upravljanja kvalitetom hrane na poslovni rezultat u hrvatskim prehrambenim poduzećima, Poslovna izvrsnost, Vol. 5, No. 1, pp. 9-32.

8. Dumičić, K., Knežević, S., (2007.), Anketno istraživanje prakse predviđanja promjena u vlastitome poslovanju i u poslovnome okruženju hrvatskih poduzeća, Ekonomski pregled, Vol. 58, No. 3-4, pp. 158-180.

9. European Union (2018), Croatia - Overview, dostupno na: https://europa.eu/european-union/about-eu/countries/member-countries/croatia_en (pristupano 16. veljače 2018.).

10. Eurostat (2011), Regions in the European Union - Nomenclature of territorial units for statistics - NUTS 2010/EU-27, Luxembourg: European Union.

11. Gogala, Z., Šimičević, V., (2005.), Korištenje statističkih metoda u hrvatskim poduzećima, Zbornik Ekonomskog fakulteta u Zagrebu, Vol. 3, No. 1, pp. 321-338.

12. Heeringa, S. G., West, B. T., Berglund, P. A. (2010), Applied Survey Data Analysis, Boca Raton: Chapman \& Hall/CRC.

13. Kish, L. (1995), Survey Sampling, New York: John Wiley \& Sons.

14. Little, R. J. A., Rubin, D. B. (2002), Statistical Analysis with Missing Data, New York: John Wiley \& Sons.

15. Mast, J., Does, R. J. M. M., (2006), Industrial statistics: a discipline with opportunities and challenges, Statistica Neerlandica, Vol. 60, No. 3, pp. 270-282.

16. Narodne novine (2007.), Odluka o Nacionalnoj klasifikaciji djelatnosti 2007. - NKD 2007., No. 58.

17. Narodne novine (2011.), Zakon o trgovačkim društvima, br. 152.

18. Narodne novine (2012.), Zakon o izmjenama i dopunama zakona o trgovačkim društvima, br. 111.

19. Narodne novine (2015.), Zakon o računovodstvu, br. 78.

20. Pejić Bach, M., Dumičić, K., Gogala, Z., (1999.), Korištenje metoda prognoziranja prodaje u hrvatskim velikim poduzećima, Ekonomski pregled, Vol. 50, No. 7-8, pp. 780-803.

21. Rothman, K. J., (1996), Lessons from John Graunt, The Lancet, Vol. 347, No. 8993, pp. 37-39. 
22. Rust, K. F., Rao, J. N. (1996), Variance estimation for complex surveys using replication techniques, Statistical Methods in Medical Research, Vol. 5, No. 3, pp. 283-310.

23. SAS (2018), SAS/STAT(R) 9.3 User's Guide: The SURVEYFREQ Procedure - RaoScott Chi-Square Test, dostupno na: http://support.sas.com/documentation/cdl/en/ statug/63962/HTML/default/viewer.htm\#statug_surveyfreq_a0000000259.htm（pristupano 13. veljače 2018.).

24. Schwarz, G., (2013), Response Rates in European Business Tendency Surveys, dostupno na: https://www.oecd.org/std/leading-indicators/WIFO\%20G.Schwarz\%20 -response $\% 20$ rates $\% 20 \mathrm{in} \% 20$ european $\% 20$ business $\% 20$ tendency $\% 20$ surveys_paper. pdf (pristupano 16. veljače 2018.).

25. Šimičević, V., (2007.), Istraživanje statističkih metoda i statističkog mišljenja u hrvatskoj poslovnoj praksi, Ekonomski pregled, Vol. 58, No. 7-8, pp. 445-464.

26. Šolak, Nj. B., (1990.), Statistika za poslovno odlučivanje, Beograd: Naučna knjiga.

27. Van Matre, J. G., Gilbreath, G. H., (1987), Statistics for Business and Economics, 3. izd., Homewood: Business Publications.

28. Žager, K., Mamić Sačer, I., Sever, S., Žager, L., (2008.), Analiza financijskih izvještaja, 2. izd., Zagreb: Masmedia.

29. Žmuk, B., (2013.), Utjecaj primjene statističkih metoda na poboljšanje rezultata poslovanja poduzeća, doktorska disertacija, Zagreb: Ekonomski fakultet.

30. Žmuk, B., (2015a), Adoption and benefits of statistical methods in enterprises: Differences between Croatian regions, South East European Journal of Economics and Business, Vol. 10, No. 1, pp. 55-65

31. Žmuk, B., (2015b), Business Sample Survey Measurement on Statistical Thinking and Methods Adoption: the Case of Croatian Small Enterprises, Interdisciplinary description of complex systems, Vol. 13, No. 1, pp. 154-166. 